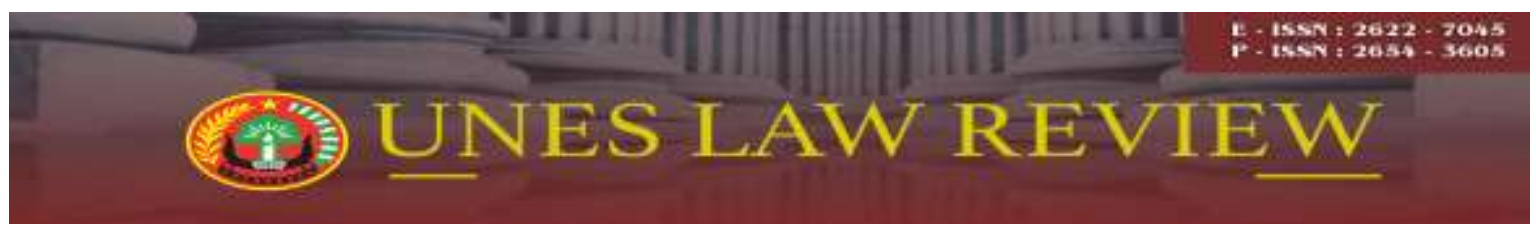

Email: uneslawreview@gmail.com

Online: http://review-unes.com/index.php/law

Volume 2, Issue 1, September 2019

\title{
MEKANISME PENGISIAN DAN PENEMPATAN DAN STOPPING DALAM POSISI DI PEMERINTAH DAERAH KOTA SOLOK
}

\author{
Johan Rafles \\ Program Magister Ilmu Hukum, Universitas Ekasakti, Padang \\ E-mail: raflesjohan@yahoo.co.id
}

\begin{abstract}
The specification of this study is descriptive analytical with the approach method used is normative juridical as the main approach and supported by an empirical juridical approach, this means taking an approach that emphasizes on the practice of the field associated with the legal aspects or legislation in force. Data sources used primary and secondary data sources and interviews were analyzed qualitatively with the results of analytical descriptive data presentation.

Based on the results of the discussion and analysis, it is obtained as follows: First, the mechanism of filling and placement and dismissal in functional positions, administrator positions, and high leadership positions for provisions and procedures as well as termination of positions are regulated in Government Regulation Number 11 of 2017 concerning PNS Management but provisions those that have not been regulated by further provisions in this PP can use existing PP provisions which may not be contradictory, including ministerial regulations that regulate technically. Second, the inhibiting factors of the mechanism for filling and placing and terminating positions in the Solok City Regional Government include: not prioritizing competence in occupying positions; the merit system has not gone well; Transfer / Transfer of Civil Servants Position between Regency / City.
\end{abstract}

Kata Kunci: Mekanisme, pengisian, dan Penempatan, Posisi, Pemerintah Daerah Kota Solok

\section{PENDAHULUAN}

Ketentuan pada Pasal 1 dan ayat 3 Undang-Undang Dasar Negara Republik Indonesia Tahun 1945 Negara Indonesia adalah negara hukum, hal ini memperlihatkan bahwa peraturan perundang-undangan mempunyai peran penting dalam Negara Indonesia. Sebagai negara hukum yang menempatkan semua tugas dan tanggung jawab negara dalam hukum positif (ketentuan peraturan perundang-undangan) relevansinya terhadap penyelenggaraan pemerintahan yang baik, salah satunya adalah dengan membentuk suatu tatanan hukum yang mengatur mengenai aparatur sipil negara yang memiliki integritas, 
profesional, netral dan bebas dari intervensi politik, bersih dari praktik korupsi, kolusi, dan nepotisme, serta mampu menyelenggarakan pelayanan publik bagi masyarakat dan mampu menjalankan peran sebagai unsur perekat persatuan dan kesatuan bangsa berdasarkan Pancasila dan Undang-Undang Dasar Negara Republik Indonesia Tahun 1945.

Undang-Undang Nomor 5 Tahun 2014 tentang Aparatur Sipil Negara lahir dalam rangka pelaksanaan cita-cita bangsa dan mewujudkan tujuan negara sebagaimana tercantum dalam Pembukaan Undang-Undang Dasar Negara Republik Indonesia Tahun 1945, dan telah menggantikan Undang-Undang Undang-Undang Nomor 8 Tahun 1974 junto Nomor 43 Tahun 1999 tentang Pokok-Pokok Kepegawaian karena sudah tidak sesuai dengan tuntutan nasional dan tantangan global.

\section{METODE PENELITIAN}

Metode Penelitian Deskriptif Analaitis dengan pendekatan yang digunakan dalam penelitian ini adalah yuridis normatif sebagai pendekatan utama dan didukung dengan pendekatan yuridis empiris. Hal ini berarti melakukan pendekatan yang menekankan pada praktek dilapangan dikaitkan dengan aspek hukum atau perundang-undangan berlaku(Hadari Namawi, 2003: 23).

\section{HASIL PENELITIAN}

Mekanisme Pengisian dan Penempatan serta Pemberhentian dalam Jabatan Fungsional di Pemerintah Daerah Kota Solok.

Pengaturan Hukum tentang Jabatan Fungsional ini syarat pengangkatan diatur pada Pasal 75 sampai dengan Pasal 81 Peraturan dan. untuk tata caranya diatur pada Pasal 81 sampai dengan 86 Peraturan serta Pelantikan dan Pengambilan Sumpah diatur pada Pasal 87 sampai dengan Pasal 93 Pemerintah Nomor 11 Tahun 2017 tentang Manajemen PNS.

Mekanisme Pengisian dan Penempatan serta Pemberhentian dalam Jabatan Fungsional di Pemerintah Daerah Kota Solok melalui Badan Kepegawaian dan Pengembangan Sumber Daya Manusia (BKPSDM) Kota Solok dilakukan sebagai berikut:

\section{a. Pengisian dalam Jabatan Fungsional}

- BKPSDM mengintruksikan seluruh OPD untuk melakukan validasi data kebutuhan tenaga jabatan fungsional

- Pejabatan Berwenang OPD/Instansi Pembina Menyampaikan rekomendasi usulan nama pejabat fungsional OPD terkait 
- BKPSDM melakukan verifikasi data pengangkatan Jabatan Fungsional yang diusulkan

- Pelaksaaan teknis dan Uji Kompetensi pada Calon Pejabat Fungsional dilaksanakan oleh instansi Pembina

- Setelah bahan lengkap terverifikasi hasil dari Uji Kompentensi dari Instansi Pembina BKPSDM menaikan Nota Dinas untuk disposisi Oleh Walikota Solok guna menetapkan mengangkat pejabat fungsional dimaksud

- BKPSDM menyiapkan jadwal dan Undangan Pelantikan kepada Pejabat Fungsional.

- Kemudian dilaksanakan Pengambilan sumpah/janji Pejabat Fungsional untuk Jabatan Fungsional Pertama.

Sedangkan Pengakatan Pejabat Fungsional melalui jalur Inpassing diatur dengan Peraturan Menteri Pendayagunaan Aparatur Negara dan Reformasi Republik Indonesia Nomor 42 Tahun 2018 tentang Pengangkatan Pegawai Negeri Sipil Dalam Jabatan Fungsional Melalui Penyesuaian/Inpassing.

\section{b. Penempatan Jabatan Fungsional}

Penempatan dalam Jabatan Fungsional ditetapkan dengan Keputusan PPK dalam bentuk Keputusan Walikota tentang penetapan Pejabat Fungsional dilingkungan Pemerintah Kota Solok dan penempatan Sesuai dengan usulan OPD terkait.

\section{c. Pemberhentian Jabatan Fungsional}

Jabatan Fungsional dapat diberhentikan apabila:

Mengundurkan diri dari jabatan, diberhentikan sementara sebagai PNS, Menjalani cuti diluar tanggungan Negara, Menjalani tugas belajar lebih dari 6 (enam) bulan, ditugaskan secara penuh diluar Jabatan Fungsional, tidak memenuhi persyaratan Tata Cara Pemberhentian dari Jabatan Fungsional:

1) Pemberhentian Jabatan Fungsional ahli utama diusulkan oleh PPK kepada Presiden yang menduduki ahli utama

2) Pemberhentian Jabatan Fungsional selain Ahli Utama ditetapkan oleh PPK. 


\section{Mekanisme Pengisian dan Penempatan serta Pemberhentian dalam Jabatan Administrasi di Pemerintah Daerah Kota Solok.}

Pejabat Administrasi adalah Pegawai ASN yang menduduki Jabatan Administrasi pada instansi pemerintah (Undang-Undang Nomor 5 tahun 2014). Jenjang Jabatan Administras terdiri atas Jabatan Administrator, Jabatan Pengawas dan pelaksana.

Kompetensi Jabatan administrator, Jabatan pengawas, dan Jabatan pelaksana harus meliputi Kompetensi Teknis, Kompetensi Manajerial, dan Kompetensi Sosial Kultural. Pengaturan hukum untuk Syarat Jabatan Administrasi ini diatur pada Pasal 50 sampai Pasal 55 dan tata cara penangkatan diatur pada Pasal 56 serta Pengambilan Sumpah diatur Pada Pasal 57 sampai dengan 63 Peraturan Pemerintah Nomor 11 Tahun 2017 tentang Manajemen PNS.

Mekanisme Pengisian dan Penempatan serta Pemberhentian dalam Jabatan Administrasi di Pemerintah Daerah Kota Solok melalui Badan Kepegawaian dan Pengembaangan Sumber Daya Manusia (BKPSDM) Kota Solok dilakukan sebagai berikut:

\section{a. Pengisian dalam Jabatan Administrasi}

- PPK Mengintruksikan BKPSDM untuk melakukan pendataan Jabatan kosong dan Jabatan yang perlu dievaluasi dilingkungan Pemerintah Kota Solok.

- BKPSDM Melakukan pendataan dan evaluasi jabatan.

- Data tersebut dibicarakan dengan Badan Pertimbangan Jabatan dan Kepangkatan Pegawai Negeri Sipil dilingkungan Pemerintah Kota Solok yang ditetapkan dengan Surat Keputusan Walikota Solok Nomor 188.45-95 TAHUN 2017 dengan susunan anggota: Seketaris Daerah Sebagai Ketua; dan sebagai Anggota Asisten Bidang Pemerintahan Sekretaria Daerah; Assiten Bidang Administrasi Umum Sekretariat Daerah; Kepala BKSDM Kota Solok.

- Buperjakat mengadakan rapat Internal untuk membicarakan usulan pengisian jabatan dimaksud.

- Hasil dari rapat tersebut dituangkan dalam Nota Dinas untuk disampaikan kepada Walikota Solok (PPK) untuk mendisposisi dan memutukan serta menetapkan pejabat (Penetapan bisa saja terjadi dengan cara Buperjakat menghubungi Walikota Solok untuk menetapkan siapa akan dilantik dalam suatu jabatan). 
- Badan Kepegawaian dan Pengembangan Sumber Daya Manusia Menyiapkan Surat Keputusan Walikota Solok tentang Pelantikan Pejabat dan Administrasi lainnya yang diperlukan.

- Pelantikan Pengambilan Sumpah/Janji Jabatan

\section{b. Penempatan Jabatan Administrasi}

Penempatan Pejabat Administrasi berdasarkan prioritas OPD mana yang akan ditempati dalam pengisian jabatan tersebut disesuaikan dengan pengalaman dan Kompetensi serta kelayakan penempatan seseorang untuk menjabat, namun tetap kesepakatan penempatan jabatan bersumber dari dari baperjakat dengan PPK.

\section{c. Pemberhentian Jabatan}

Pemberhentian dan Tata Cara memberhentikan Jabatan Administrator, sebagai berikut: Pemberhentian dari Jabatan Administrasi PNS, diberhentikan dari Jabatan Administrasi apabila:

1) mengundurkan diri dari Jabatan;

2) diberhentikan sementara sebagai PNS;

3) menjalani cuti di luar tanggungan negara;

4) menjalani tugas belajar lebih dari 6 (enam) bulan;

5) ditugaskan secara penuh di luar JA; atau

6) tidak memenuhi persyaratan Jabatan. Dalam keadaan tertentu, permohonan pengunduran diri dapat ditunda untuk paling lama 1 (satu) tahun.

7) Pejabat administrator dapat juga diberhentikan apabila tidak melaksanakan kewajiban untuk memenuhi persyaratan kualifikasi dan tingkat pendidikan.

8) Pejabat dapat diangkat kembali sesuai dengan Jabatan Admnistrasi yang terakhir apabila tersedia lowongan Jabatan.

Tata Cara Pemberhentian dari Jabatan Administrasi (Peraturan Pemerintah Nomor 11 Tahun 2107):

1) Pemberhentian dari Jabatan Administrasi diusulkan oleh Pejabat bersangkutan kepada PPK.

2) PPK menetapkan keputusan pemberhentian dalam JA.

3) PPK dapat memberikan kuasa kepada pejabat di lingkungannya untuk menetapkan pemberhentian dalam Jabatan Administrasi. 
4) Ketentuan lebih lanjut mengenai tata cara pemberian kuasa dalam pemberhentian dari Jabatan Administrasi dengan Peraturan Menteri.

\section{Mekanisme Pengisian dan Penempatan serta Pemberhentian dalam Jabatan Administrasi di Pemerintah Daerah Kota Solok}

Jabatan Pimpinan Tinggi adalah sekelompok jabatan tinggi pada instansi pemerintah. Pejabat Pimpinan Tinggi adalah Pegawai ASN yang menduduki Jabatan Pimpinan Tinggi (Undang-Undang Nomor 5 Tahun 2014 tentang Aparatur Sipil Negara). Jabatan Pimpinan Tinggi terdiri dari Jabatan Pimpinan Tinggi, Utama Jabatan Pimpinan Tinggi, Madya, Jabatan Pimpinan Tinggi Pratama.

Mekanisme Pengisian dan Penempatan serta Pemberhentian dalam Jabatan Pimpinan Tinggi di Pemerintah Daerah Kota Solok melalui Badan Kepegawaian dan Pengembaangan Sumber Daya Manusia (BKPSDM) Kota Solok dilakukan sebagai berikut:

\section{a. Pengisian dalam Jabatan Pimpinan Tinggi}

Dasar Hukum Kebijakan Jabatan Pimpinan Tinggi melalui Seleksi Terbuka, adalah sebagai berikut : Pasal 108, Pasal 109, Pasal 110, Pasal 116, Pasal 117, Pasal 118 dan Pasal 120 Undang-undang Nomor 5 tahun 2014 tentang Aparatur Sipil Negara; Pasal 205, Pasal 208, Pasal 233, Pasal 234 dan Pasal 235 Undang-Undang Nomor 23 Tahun 2014 tentang Pemerintah Daerah Peraturan Pemerintah Daerah; Nomor 11 Tahun 2017 tentang Manajemen PNS; Peraturan Menteri PANRB Nomor 13 Tahun 2014 tentang Tata Cara Pengisian Jabatan Pimpinan Tinggi Pratama Melalui Seleksi Terbuka di Lingkungan Instansi Pemerintah.

Sebagaimana diatur pada Pasal 115 sampai dengan Pasal 129 Peraturan Pemerintah Nomor 11 Tahun 2017 tentang Manajemen ASN mengatur secara rinci mengenai tata cara pengisian Jabatan Pimpinan Tinggi yang sebelumnya masih menggunakan Peraturan Menteri PANRB Nomor 13 Tahun 2014 tentang Tata Cara Pengisian Jabatan Pimpinan Tinggi Pratama Melalui Seleksi Terbuka di Lingkungan Instansi Pemerintah. Adapun mekanisme pengisian dalam Jabatan Pimpinan Terbuka sebagai berikut:

a) Persiapan 
- Pembentukan Panitia Seleksi yang ditetapkan oleh Walikota Solok berkoordinasi dengan KASN dan Menteri Dalam Negeri dan Menpan. Panitia Seleksi terdiri dari pejabat dari instansi bersangkutan, pejabat dari Instansi lain yang berkaitan dengan tugas jabatan yang lowong, akademis/pakar/ profesional Pelaksanaan

- Pengumuman

- Seleksi Administrasi

b) Seleksi Kompetensi

c) Wawancara Akhir

d) Penelusuran Rekam Jejak

e) Hasil Seleksi

f) Tes Kesehatan dan Psikologi

g) Pembiayaan

h) Monitoring dan Evaluasi

Dalam hal ini BKPSDM hanya mefasilitasi Panitia Seleksi dan pihak BKSDM sebagai Sekretariat dalam kepanitiaan.

\section{b. Penempatan Jabatan Pimpinan Tinggi}

Untuk Penempatan Jabatan PimpinanTinggi harus disesuaikan dengan Kompetensi dan Sistem Merit serta bebas dari segala intervensi sesuai dengan peraturan perundang-undangan untuk peningkatan manajamen PNS. Namun Penempatan Pejabat Pimpinan Tinggi sepenuhnya hak PPK untuk menentukan penempatan.

\section{c. Pemberhentian Jabatan Pimpinan Tinggi}

Pemberhentian Jabatan Pimpinan Tinggi Peraturan Pemerintah Nomor 11 Tahun 2017 tentang Manajemen PNS pada Pasal Pasal 144, dimana PNS diberhentikan dari JPT apabila mengundurkan diri dari Jabatan; diberhentikan sebagai PNS; diberhentikan sementara sebagai PNS; menjalani cuti di luar tanggungan negara; menjalani tugas belajar lebih dari 6 (enam) bulan; ditugaskan secara penuh di luar Jabatan Pimpinan Tinggi; terjadi penataan organisasi; atau tidak memenuhi persyaratan Jabatan. 
Tata Cara Pemberhentian dari Jabatan Pimpinan Tinggi, Pemberhentian dari Jabatan Pimpinan Tinggi diusulkan oleh:

1) Menteri yang mengoordinasikan kepada Presiden bagi PNS yang menduduki Jabatan Pimpinan Tinggi utama;

2) PPK kepada Presiden bagi PNS yang menduduki Jabatan Pimpinan Tinggi madya;

3) Pejabat lain kepada Presiden bagi Pejabat Pimpinan Tinggi madya di lingkungan kesekretariatan lembaga negara;

4) Menteri kepada Presiden bagi Pejabat Pimpinan Tinggi madya di lingkungan lembaga nonstruktural; dan

5) Pejabat yang berwenang kepada PPK bagi PNS yang menduduki JPT pratama.

6) Pemberhentian dari JPI utama dan JPT madya ditetapkan oleh Presiden.

7) Pemberhentian dari JPT pratama ditetapkan oleh PPK.

Ketentuan lebih lanjut mengenai tata cara pemberhentian dari JPT diatur dengan Peraturan Menteri.

\section{Analisis Mekanisme Pengisian dan Penempatan serta Pemberhentian dalam Jabatan di Pemerintah Daerah Kota Solok}

Mekanisme Pengisian dan Penempatan serta Pemberhentian dalam Jabatan di Pemerintah Daerah Kota Solok dilihat dari segi Peraturan Perundangan-undangan masih belum maksimal dapat dilaksanakan sesuai dengan Peraturan-Perundangan terbaru.

Dimana mekanisme pengisian dan penempatan serta pemberhentian Jabatan wajib berpedoman kepada Undang-Undang Nomor 5 Tahun 2014 tentang Aparatur Sipil Negara dan Pelaksananya Peraturan Pemerintah Nomor 11 Tahun 2017 tentang Manajemen PNS, namun ketentuan Peraturan Pemerintah yang bersumber pada Undang-Undang Nomor 43 Tahun 1999 tentang Pokok-Pokok Kepegawaian masih menjadi pedoman termasuk peraturan menteri yang mengatur secara teknis karna aturan pelaksana dan pelaksana secara teknis belum sepenuhnya diatur dalam Peraturan Pemerintah Nomor 11 Tahun 2017.

Untuk Peraturan Menteri tidak berlaku apabila dicabut oleh Peraturan Menteri lain atau peraturan perundang-undangan yang lebih tinggi (seperti Peraturan Pemerintah atau Peraturan Presiden) yang secara tegas mencabut Peraturan Menteri dari undang-undang yang lama. Jika terdapat Peraturan Menteri baru yang substansinya mengatur materi yang 
sama dengan Peraturan Menteri yang lama (walaupun tanpa klausul pencabutan secara tegas), maka Peraturan Menteri yang lama menjadi tidak berlaku berdasarkan asas lex posteriori derogate legi generalis.

Pada Pasal 87 Undang-Undang Nomor 12 Tahun 2011 tentang Pembentukan Peraturan Perundang-undangan juga menyebutkan:

Peraturan perundang-undangan mulai berlaku dan mempunyai kekuatan mengikat pada tanggal diundangkan, kecuali ditentukan lain di dalam peraturan perundang-undangan yang bersangkutan. Hal ini ditegaskan pula sebagaimana diatur dalam Peraturan Pemerintah Nomor 11 Tahun 2017 pada Pasal berikut:

Pasal 352

"Pangkat dan golongan ruang PNS yang sudah ada pada saat Peraturan Pemerintah ini mulai berlaku, tetap berlaku sampai dengan diberlakukannya ketentuan mengenai gaji dan tunjangan berdasarkan Peraturan Pemerintah mengenai gaji dan tunjangan sebagai pelaksanaan Undang-Undang Nomor 5 Tahun 2014 tentang Aparatur Sipil Negara.”

Pasal 363

"Peraturan pelaksanaan dari peraturan perundang-undangan yang mengatur mengenai penyusunan dan penetapan kebutuhan, pengadaan, pangkat dan Jabatan, pengembangan karier, pola karier, promosi, mutasi, penilaian kinerja, penggajian dan tunjangan, penghargaan, disiplin, pemberhentian, jaminan pensiun dan jaminan hari tua, dan perlindungan, dinyatakan masih tetap berlaku sepanjang tidak bertentangan atau belum diganti berdasarkan ketentuan dalam Peraturan Pemerintah ini."

Dari isi pasal Peraturan Pemerintah tersebut dapat penulis analisis bahwa ketentuanketentuan yang belum diatur lebih lanjut dengan Peraturan Pemerintah dan Peraturan Menteri maka peraturan yang masih ada dapat menjadi pedoman sebagai pelaksananya maupun pelaksanaan secara teknisnya. Akan tetapi ketentuan yang telah dijelaskan secara rinci pada Peraturan Pemerintah Nomor 11 Tahun 2017 tentang Manajemen PNS wajib dipedomani sebagai dasar acuan dalam pelaksanaannya.

Analisis Mekanisme pengisian, penempatan dan Pemberhentian Jabatan Fungsional Badan Kepegawaian dan Pengembangan Sumber Daya Manusia dalam Pelaksanaannya sudah merujuk kepada Undang-Undang Nomor 5 Tahun 2014 tentang Aparatur Sipil Negara dan Peraturan Pemerintah Nomor 11 Tahun 2017 tentang Manajemen PNS serta 
Kententuan Menteri yang menyangkut bidang jabatan fungsional itu sendiri. Namun untuk kepangkatan jabatan dan Golongan jabatan fungsional masih berujuk kepada Peraturan Pemerintah Nomor 100 Tahun 2000 tentang Pengangkatan Pegawai Negeri Sipil dan Jabatan sebagaima telah dirubah dengan Peraturan Pemerintah 13 tahun 2002.

Analisis Mekanisme Pengisian Jabatan Administrasi masih menggunakan Baperjakat sebagai badan petimbangan dalam pengakatan jabatan Pegawai Negeri Sipil untuk pengaturan hukum pada Peraturan Pemerintah Nomor 100 Tahun 2000 tentang Pengangkatan Pegawai Negeri Sipil dalam Jabatan sebagaima telah dirubah dengan Peraturan Pemerintah 13 tahun 2002.

Padahal Baperjakat tidak ada lagi diatur pengaturan hukumnya pada Undang-Undang Nomor 5 Tahun 2014 tentang Aparatur Sipil Negara maupun pada Peraturan Pemerintah Nomor 11 Tahun 2017 tentang Manajemen PNS.

Seharusnya untuk mekanisme pengisian, penempatan, dan pemberhentian Jabatan Administrasi ini berpedoman kepada Peraturan Pemerintah Nomor 11 Tahun 2017 tentang Manajemen PNS pasal 56 dan adanya pelaksanaan uji Kompetensi. Pada Data Laporan Bulan Kepegawaian BKSDM dari Desember sampai dengan April 2009 tentang PNS Berjabatan menurut Pendidikan tamatan SLTA berjumlah 47 orang yang terdiri: dari eselen III b 1 orang; Eselon IV a 32 orang; Eselon IV b 12 orang; Eselon Va 2 orang. Hal ini tidak sesuai dengan persyaratan yang diatur pada pasal 54 Peraturan Pemerintah terutama klasifikasi Pendidikan bahwa syarat pendidikan untuk Jabatan Administrasi adalah S1 setara dengan D IV sedangkan jabatan Pengawas S1 setara DIV paling rendah D3. Namun suatu sisi pemerintah memberikan kebijakan atau kesempatan kepada para pejabat yang belum menyesuaikan ijazahnya akan diberikan kesempatan 5 tahun untuk menyesuaikan penyesuaian kompetensi pendidikan.

Jika dalam kurun lima tahun tidak mengambil ijazah maka akan dikembalikan menjadi staf. Akan tetapi jelas diatur dalam pengaturan hukum tata cara pemberhentian pejabat administrasi pada Pasal 64 angka (1) huruf $\mathrm{f}$ disebutkan pejabat administrasi dapat diberhentikan apabila tidak memenuhi persyaratan. Termasuk syarat Pengalaman jabatan Pengawas masih berpedoman kepada Peraturan Pemerintah Nomor 100 Tahun 2000 tentang Pengangkatan Pegawai Negeri Sipil Dalam Jabatan Struktural sebagaimana telah diubah dengan Peraturan Pemerintah Nomor 13 Tahun 2002, bahwa Pangkat/terendah 
adalah Penata Muda Tk. I III/b. pada Peraturan Pemerintah Nomor 11 Tahun 2017 tentang Manajemen PNS pada Pasal 54 angka 3 huruf d dijelaskan bahwa syarat Pendidikan Paling rendah Diploma III. Dan kedepan diharapkan khusus untuk Jabatan Administrator ini Pemerintah Kota Daerah Solok dilaksanakan secara terbuka seperti yang telah dilakukan daerah lain.

Analisis Mekanisme pengisian, penempatan, dan pemberhentian jabatan pimpinan tinggi yang sebelumnya masih berpedoman dengan Peraturan Menteri Aparatur dan Reformasi Biokrasi Nomor 13 Tahun 2014 tentang Tata Cara Pengisian Jabatan Tinggi Secara Terbuka namun setelah Peraturan Pemerintah Nomor 11 Tahun 2017 tentang Manajemen PNS lebih jelas mengatur tentang Seleksi jabatan Pimpinan Tinggi Secara Terbuka pada Pasal 110 sampai dengan Pasal 128 dan pada Pasal 129 ditegaskan pula bahwa PPK dilarang mengisi Jabatan yang lowong dari calon pejabat pimpinan tinggi yang lulus seleksi pada JPT yang lain.

Seleksi Jabatan dilakukan secara terbuka dapat memberi peluang semua PNS yang telah memenuhi syarat untuk mengusulkan dirinya sesuai dengan jabatan lowongan yang tersedia sehingga manajamen PNS dan Sistem Merit dapat berjalan secara efektif dan berkelanjutan melalui Pengawasan Komisi Apatur Sipil Negara (KASN).

\section{PENUTUP}

Untuk mekanisme pengisian, penempatan, dan pemberhentian di Pemerintah Daerah Kota Solok merujuk pada Undang-Undang Nomor 5 Tahun 2014 tentang Aparatur Sipil Negara dan Peraturan Pemerintah Nomor 11 Tahun 2017 tentang Manajemen PNS disamping juga Peraturan Pemerintah dan Peraturan Menteri yang masih berlaku. Dimana peraturan tersebut mengatur persyaratan dan tata cara pengangakatan dalam pengisian, penempatan dan pemberhentian dalam Jabatan Fungsional, Administrasi, Jabatan Pimpinan Tinggi secara efektif yang menjadi acuan utama, namun suatu sisi diperlukan peraturan yang mengatur secara teknis.

Untuk menjaga netralitas, independensi serta dipatuhinya norma hukum yang ada terkait pengangkatan jabatan maka diperlukan mekanisme pengisian, penempatan, dan pemberhentian jabatan yang akurasi sehingga dapat tercipta manajemen PNS yang baik dan berjalannya sistem merit dengan efektif. Sehingga yang diharapkan dalam tujuan negara sebagaimana yang termasuk didalam pembukaan Undang-Undang Dasar Negara 
Republik Indonesia tahun 1945 dapat terwujud dengan lahirnya pejabat yang memiliki kompetensi, kualifikasi serta mampu bekerja secara adil dan wajar dalam menjalankan tugasnya diinstansi pemerintahan.

Faktor-Faktor penghambat mekanisme pengisian, penempatan dan pemberhentian jabatan di Pemerintah Kota Solok, diantaranya belum memproritaskan kompetensi dalam menduduki jabatan dapat dilihat dari persyaratan tingkat pendidikan, belum dilaksanakannya uji kompetensi pada pengisian jabatan Administrasi dan masih banyak pejabat yang belum mengikuti pendidikan dan latihan Kepemimpinan (PIM); sistem merit belum berjalan dengan baik karena the right man and the right place belum terealisasi dengan baik; Perpindahan/Mutasi Jabatan PNS antar daerah Kabupaten/Kota dimana kecilnya kesempatan pengembangan karier PNS yang mengabdi didaerahnya sendiri yang diakibatkan perindahan/mutasi PNS dari daerah lain.

\section{DAFTAR PUSTAKA}

\section{Buku Teks:}

Ambar Teguh Sulistiyani dan Rosidah, Manajemen Sumber Daya Manusia, Graha Ilmu, Yogyakarta, 2003.

Bambang Sunggono, Metodologi Penelitian Hukum, PT. Raja Grafindo Persada, Jakarta, 2003.

Budiman B.Sagala, Tugas dan Wewenang MPR di Indonesia, Ghalia Indonesia, Jakarta, 1982.

Burhannudin A. Tayibnapis, Administrasi Kepegawaia, Suatu Tinjauan Analitik, Pradnya Paramita, Jakarta, 1995.

Burhanudin A Tayibnapis, Administrasi Kepegawaian, SuatuTinjauan Analitik, Pradnya Paramith, Jakarta, 1986.

Hadari Namawi dalam Soejono, Metode Penelitian Hukum, Rineka Cipta, Jakarta, 2003.

Jum Anggriani, Hukum Administrasi Negara, Graha Ilmu, Yogyakarta, 2012.

Kadarisman Muh, SH,M.Si, Manajemen Aparatur Sipil Negara, Raja Grafindo Persada, Depok, 2018.

Kansil, C.S.T., Sistem Pemerintahan Indonesia, Rajawali Press, Jakarta, 2005.

Moh.Mahfud MD, Hukum Kepegawaian Indonesia, Liberty, Yogyakarta, 1988.

Muchsan, Hukum Kepegawaian, Bina Aksara : Jakarta, 1982.

Palan, Compentency Management:Teknis Mengimplementasikan Manajemen Sumber Daya Manusia Berbasis Kompentensi Untuk Meningkatkan Daya Saing Organisasi, PPM, Salemba Empat, Jakarta, 2007. 
Rajudi Atmosudirdjo, Hukum Adiministrasi Negara, Ghalia Indonesia, Jakarta, 1981.

Sastra Djatmika dan Marsono, Hukum Kepegawaian di indonesia, Djambatan, Jakarta, 1995.

SF. Marbun, et.al. Hukum Administrasi Negara, UII Press, Yogyakarta, 2001.

Soerjono Soekanto, Pengantar Penelitian Hukum, Universitas Indonesia, Jakarta, 2006.

Sondang P Siagian, Filsafat administrasi, Gunung Agung, Jakarta, 1996.

W.J,S Poerwadarminta, Kamus Besar Bahasa Indonesia, Jakarta, 1986.

Pustaka Primer (Journal) :

Indaru Setyo Nurprojo, Merit System Dan Politik Birokrasi Di Era Otonomi Daerah, Jurnal Kebijakan dan Manajemen PNS VOL. 8, No.1, Juni 2014, Jurusan Ilmu Politik FISIP Universitas Jenderal Soedirman.

BKN, 2018, Dikotomi Sistem Merit Dan Politisasi Birokrasi Dalam Pengangkatan Jabatan ASN, Nomor: 019-Mei 2018, Pusat Pengkajian dan Penelitian Pegawai, Policy Brief BKN.

Rencana Strategis Kerja Badan Kepegawaian dan Pengembangan Sumber Daya Manusia Kota Solok Tahun 2016-2021, hlm IV-1

Laporan Bulanan Kepegawaian BKPSDM Kota Solok Desember 2018-April 2019

http://www.definisimenurutparaahli.com/pengertian-mekanisme/.

https://id.wikipedia.org/wiki/Jabatan_Fungsional_Aparatur_Sipil_Negara.

https://id.wikipedia.org/wiki/Jabatan_Pimpinan_Tinggi_Aparatur_Sipil_Negara\#Jjabatan_ pimpinan_tinggi_utama_dan_madya.05.Policy-Brief-Mei-2018\%20(1).pdf,

http://m.hukumonline.com/klinik/detail/ulasan/it5943825cc413c/keberlakuan-peraturanpemerintah-yang-belum-ada-peraturan-pelaksanaannya/.

https://www.menpan.go.id/site/cerita-sukses-rb/menuju-smart-asn-2019.

https://ejournal.undip.cid/index.php/politika/article/view/4879/4425.

http://id.wikipedia.org/wiki/pemerintah-daerah-di-indonesia

\section{Peraturan Perundang-undangan :}

Undang-Undang Dasar Negara Republik Indonesia Tahun 1945.

Undang-Undang Nomor 43 Tahun 1999 tentang Perubahan atas Undang-Undang Nomor 8 Tahun 1974 tentang Pokok-Pokok Kepegawaian (Lembaran Negara RI Tahun 1999 Nomor 169 dan Tambahan Lembaran Negara RI Tahun 1999 Nomor 3890).

Undang-Undang Nomor 12 Tahun 2011 tentang Pembentukan Peraturan PerundangUndangan (Lembaran Negara Republik Indonesia Tahun 2011 No 82. Penjelasannya tercatat dalam Tambahan Lembaran Negara Republik Indonesia Nomor 5234) 
Undang Undang Republik Indonesia Nomor 5 Tahun 2014 tentang Aparatur Sipil Negara (Lembaran Negara RI Tahun 2014 Nomor 6 dan Tambahan Lembaran Negara RI Tahun 2014 Nomor 5494).

Undang Undang Republik Indonesia Nomor 30 Tahun 2014 tentang Administrasi Pemerintahan (Lembaran Negara RI Tahun 2014 Nomor 292 dan Tambahan Lembaran Negara RI Tahun 2014 Nomor 5601).

Peraturan Pemerintah Republik Indonesia Nomor 11 Tahun 2017 tentang Manajemen Pegawai Negeri Sipil No.63, 2017 ADMINISTRASI. Kepegawaian. PNS. Manajemen. Pencabutan. (Penjelasan dalam Tambahan Lembaran Negara Republik Indonesia Nomor 6037)

Peraturan Pemerintah Republik Indonesia Nomor 53 Tahun 2010 tentang Disiplin Pegawai Negeri Sipil (Lembaran Negara RI Tahun 2010 Nomor 74 dan Tambahan Lembaran Negara RI Nomor 5135).

Peraturan Pemerintah Nomor 99 Tahun 2000 tentang Kenaikan Pangkat PNS sebagaimana dirubah dengan Peraturan Pemerintah Nomor 12 Tahun 2002. (Lembaran Negara Tahun 2002 Nomor 32, Tambahan Lembaran Negara Nomor 4193)

Peraturan Pemerintah Nomor 100 Tahun 2000 tentang Pengangkatan Pegawai Negeri Sipil Dalam Jabatan sebagaimana diubah dengan Peraturan Pemerintah Nomor 13 Tahun 2002 (Lembaran Negara Tahun 2000 Nomor 197, Tambahan Lembaran Negara Nomor 4018 dan Lembaran Negara RI Tahun 2002 Nomor 33)

Peraturan Menteri Pendayaugunaa Aparatur Negara dan Reformasi Biokrasi Nomor 13 Tahun 2014 tentang Tata Cara Pengisian Jabatan Pimpinan Tinggi Secara Terbuka di Lingkungan Instansi Pemerintah (Berita Negara RI Tahun 2014 Nomor 477)

Peraturan Menteri Pendayagunaan Aparatur Sipil Negara dan Reformasi Biokrasi Nomor 38 Tahun 2018 tentang Standar Kompetensi Jabatan Aparatur Sipil Negara (Berita Negara Tahun 2017 Nomor 1907)

Peraturan Menteri Aparatur Negara dan Reformasi Biokrasi Nomor 42 Tahun 2018 tentang Pengangkatan Pegawai Negeri Sipil Dalam Jabatan Fungsional Melalui Penyesuaian/Inpassing (Berita Negara RI Tahun 2018 Nomor 1274) 